\section{Equity and accessibility in health? Out-of-pocket expenditures on health care in middle income countries: evidence from Mexico}

\author{
¿Equidad y accesibilidad en salud? Gasto personal \\ de los usuarios en países de ingresos medios: \\ evidencias desde México
}

\begin{abstract}
${ }_{1}^{1}$ Centro de Investigación en Sistemas de Salud, Instituto Nacional de Salud Pública, Cuernavaca, México. 2 Universidad Autónoma de Yucatán, Mérida, México.

3 Pan American Health Organization, Washington DC, U.S.A.

Correspondence

A. Arredondo

Centro de Investigación en Sistemas de Salud, Instituto Nacional de Salud Pública. Av. Universidad, 655 Col. Sta. Maria Ahuacatitlán 62508 Cuernavaca, Morelos, México. aarredon@insp.mx aarredondo@fant.uady.mx
\end{abstract}

\begin{abstract}
This study analyzes the results of a cross-sectional survey which set out to determine the costs to patients of searching for and receiving health care in public and private institutions. The information analyzed was obtained from the study population of the Mexican National Health Survey. The dependent variable was the out-of-pocket users' costs and the independent variables were the insurance conditions, type of institution and income. The empirical findings suggest that there is a need for a more detailed analysis of user costs in middle income countries in general, where the health system is based on social security, public assistance and private institutions. This study shows that the out of pocket costs faced by users are inequitable and fall disproportionately upon socially and economically marginalized populations.
\end{abstract}

Equity in Health; Health Services Accessibility; Health Expenditures
Armando Arredondo 1,2

Patricia Nájera ${ }^{3}$

\section{Introduction}

In recent years, health sector research at international, national, regional and local levels, has come to rely more on economics $1,2,3$.

In middle income countries, considerable effort has been made recently to do more to meet the population's health needs. There remains, however, a lack of inter and intra-institutional agreement on how best to achieve this, largely because of the difficulty in measuring productivity, costs and procedures across different levels of care 4,5 . This has resulted in a realization that the creation and implementation of norms are not enough to ensure and/or to evaluate efficiency, as well as the fact that the information necessary to do so does not exist 6,7 .

With respect to the costs of health care, there is a need for two forms of analysis: the costs to the provider of producing services, and the costs to the user of searching for and obtaining services 8 . This latter has been little developed in middleincome countries. The objective of this article is to generate information regarding this issue, specifically on the costs to users of ambulatory care in Mexico.

This study is based on the results of a national health survey carried out in Mexico. It aims to identify economic indicators that allow us to analyze equity and accessibility in Mexican healthcare. For this, the paper presents and discusses findings on the costs of ambulatory care disag- 
gregated by transport, consultations and medicines ${ }^{9}$. Additionally, the results are considered in a conceptual framework, which allows identification of the different events, from the users' point of view, which occur in the process of searching for and obtaining health care.

\section{Conceptual considerations}

\section{The concept of costs}

The economic cost of a unit of resource is the benefit that would be obtained from the best alternative use. In the case of health services, and for the purpose of this analysis, user costs are defined as the sum of economic resources that users expend while searching for and obtaining health care 10 .

Various studies have considered the analysis of costs in health care. See for example Mills \& Gilson 11; Drummond \& Stoddart 12; Dunlop \& Zubkoff 13 . In the case of middle income countries, we propose the following classification: (a) direct costs: these include all monetary costs of generating and providing health services and all direct payments by the consumer in the process of obtaining health care; (b) indirect costs: include all costs, in terms of time and money, incurred by the consumer while searching for and obtaining health care, including user payments, travel time, and the time involved in waiting and treatment.

The costs and the process of searching for and obtaining health care

As proposed by Donabedian 14, the health care process is fundamentally conceived as two chains of activities and processes where the health care provider and the consumer participate in a parallel but not wholly separate manner. The activities that constitute the health care process arise as a response to a need that is generally perceived as an alteration or disturbance in health and wellbeing. In some cases, the health professional may be the first one to detect it and this may trigger the process leading to health care.

The process of searching for care leads to direct contact with the provider. This may be on account of the person's own information and initiative or with help from friends and relatives who may constitute what Freidson 15 calls the "nonprofessional system of references". These activities constitute the diagnostic, decision-making and therapeutic process in which a "professional system of references" intervenes to establish a pattern in the use of services and in the cost the user pays 16 .
The two main axes of the health care search process, the provider's behavior and the consumer's behavior, come together when health care is obtained. This should result in some improvement in the need that triggered the process in the first place 17,18. The process of searching for and obtaining health care is dynamic and complex and involves social, psychosocial, epidemiological and cultural variables which are specific to the population, as well as six political-administrative variables that belong to the health system and which bring both actors into contact to try to resolve a particular health problem 19

Based on these considerations, for the purpose of analyzing the National Health Survey findings on out-of-pocket user payments, we identified as direct costs the costs of the diagnostic process, of health care (consultation) and of drugs; and as indirect costs, the cost of searching for care (i.e. the costs of travel-transportation). The analysis in this article covers the population's behavior from the time someone perceives a health problem and proceeds to place a demand on one or other of the three main health care institutions: those for the uninsured; those for the insured population; and those for people who are able to pay (for more details on the structure of the health system, see Arredondo \& Orozco 20).

\section{Material and methods}

For the purposes of the surveys in this study, the country was divided into five regions, each with the same number of households selected $(2,523)$. This allowed for conclusions to be drawn at a regional level. To select the households, a stratified polystage sampling was performed, using the jurisdictional household sample framework of the Health Secretariat. A total of 12,615 households was visited and information was obtained on health perception and use of health services for 61,524 individuals. The response rate was $96.7 \%$.

The survey was based on two questionnaires, one directed at all people residing in the selected households at the time of the survey and the other to everyone who said he/she had used health services during the fifteen days prior to the collection of the information. In the first questionnaire the informant was, usually, the female head of household, and thereafter, other women aged 18 or over, or men from the same age range. In the second questionnaire, the informant was the user of the health service or, where this person was under age 15, his/her mother or whoever was responsible for the minor. For this latter questionnaire, two indicators of use were adopted: any use of primary care in the fifteen days prior to the 
interview and hospitalization in the last year. To assess the need for care, the self-assessed state of health, morbidity and severity were included 9 .

After identifying the total number of primary health care users, as well as the general characteristics of the health care, an appointment was programmed with the user - or adult in charge - in order to carry out an in-depth interview about the characteristics of the processes of seeking and obtaining health care, including indicators of institution, human resources, travel and waiting times, costs and perceptions of the whole process.

Costing was conducted as follows: according to the person's insurance condition, in terms of eligibility for social security, as reported by the population (insured/uninsured); the average annual household income per capita and the type of institution where health care was used, grouped according to four categories: social security units (Mexican Institute of Social Security - IMSS and the Institute of Services and Social Security for State Workers - ISSSTE), health ministry units, private services (for profit institutions) and other institutions (including private charities and other public institutions). All costs and incomes were converted into U.S. dollars as of January 2006 (10.50 Mexican pesos per 1.00 U.S. dollar). The cost items included were direct out-of-pocket payments by users. These were costs of travel to the health care unit, financial costs of care, cost of drugs, cost of laboratory tests and other costs incurred by the user.

Extreme values (i.e. values considered to be outside the observable range) were excluded. Differences were analyzed according to the average costs by type of institution. In the second phase of the analysis, relationships were sought between costs and the socioeconomic status of the study population. Mean cost differences were analyzed by type of institution, by insurance condition and by family income. In order to compare the differences among mean values of the groups obtained in the Anova single classification, statistical tests were applied using the Duncan test.

\section{Results}

The estimated number of users of services was nearly 4.7 million and of these, nearly 3 million made some kind of payment for the services used. The average cost of transport was US $\$ 2.20$, that for a consultation US\$ 7.99. For those who were issued with a prescription, the average cost of medicine was US\$ 9.60, and among those who had some kind of test, the average payment was US\$ 13.60 (Figure 1).
The average cost per user of day care was US\$ 22.70. The greatest cost was for private services (an average of US\$ 45.70), followed by Health Secretariat services (US\$17.10), other public institutions for the uninsured population (US\$ 12.10) and, finally, uninsured users who received care at social security institutions (US\$ 8.60) (Figure 1). The average cost of transportation, US\$2.20, is high considering it represents about $50 \%$ of the average daily income. Costs of travel showed considerable differences across users of social security services and private services: for the former, the average was US $\$ 1.60$, while for the latter it was US\$2.80. Observed differentials were greater (US\$ 4.11) for users in rural communities, compared with those in urban areas (US\$ 1.68).

As we predicted, the costs of consultations varied considerably according to the institution: US\$ 0.70 at social security establishments (this low cost is explained by the fact that this care is primarily for the uninsured), US $\$ 4.10$ at Health Secretariat units; US\$ 20.40 at private sector services; and US\$ 3.60 at other public services for the general population. For users, medicines have a similar cost as care itself; on average, US\$ 9.60. This varied in the different sectors: at social security institutions, US\$ 1.40; at Health Secretariat institutions, US\$ 9.10; and in the private sector, US\$17.00 (Table 1).

The costs of diagnostic services averaged US\$ 13.50 and are therefore greater than the consultation itself and the medication. They varied from US\$ 1.50 at the social security services to US\$ 32.30 for private services. Average costs under this heading were US\$17.60 for the uninsured population and US\$31.20 for other public services. Analyzing the costs by type of institution, insurance condition and annual household income (Table 2), in the case of the uninsured population receiving care at a social security institution and the uninsured population receiving care at a Health Secretariat institution, there is an inverse relationship for costs of transportation whereby these costs are higher for those on lower incomes. A similar relationship is observed in the case of those receiving care in the private sector or another type of institution. It is interesting to note that in the case of the insured population receiving care at the social security institution, a similar inverse relationship holds.

In the analysis of the relationship between the cost of consultation by type of institution, insurance condition and annual household income, independently of whether or not insured and of the type of institution where the consultation took place, there was found to be a direct relationship between these two variables: at higher 
Figure 1

Costs to users of ambulatory health services, by type of institution (in US\$).

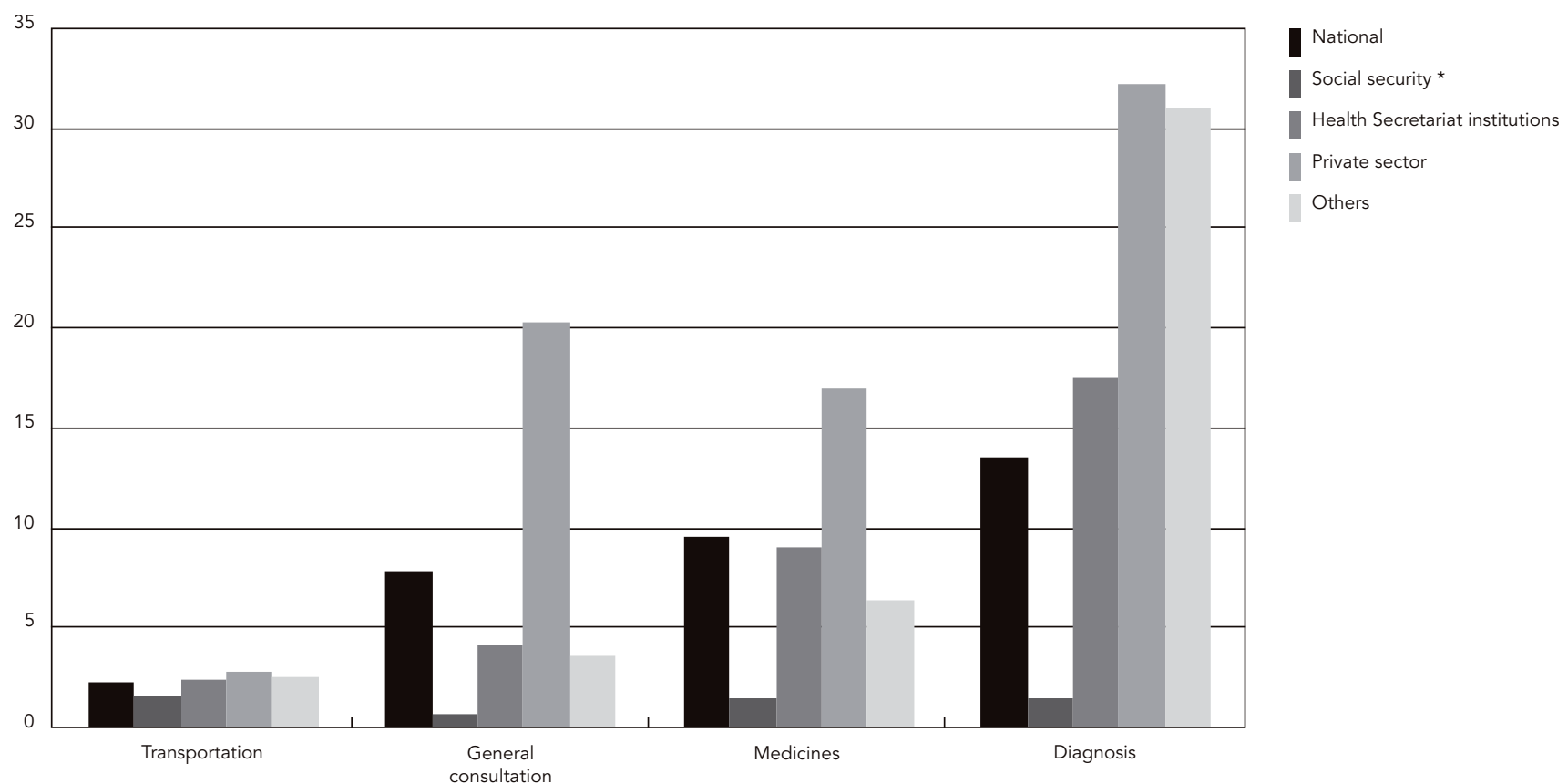

* Uninsured users who received care at social security institutions.

Notes: Duncan's test $(<0.05)$; exchange rate at 10.5 Pesos per US\$1.00. January, 2006.

incomes, costs of consultation are also higher. Only in the case of the uninsured who received care at a private for-profit institution did we not find this relationship (Table 2).

With respect to the relationship between costs of diagnostic studies by insurance status, type of institution and annual household income, in the case of the uninsured population receiving care at a social security institution, there was a negative correlation: at lower income levels, the cost of diagnostic services is greater. Something similar, though not as clear, is observed in the case of the uninsured population receiving care through the Health Secretariat. The same relationship but with a lower correlation arises for those receiving care from the private sector or at another type of institution. With respect to the type of institution, cost, income, insurance and condition, for each type of cost except medicines, there were higher costs in the private sector. For medicines, the higher cost in the private sector only held good for type of institution.

National average costs, not differentiated by type of institution and phases of the ambulatory care process, are presented in Figure 2. The costs of diagnostic studies and drugs make up the bulk of the total costs. The cost of transport represents a small part of the total. These findings are discussed in more detail in the next section where consideration is given to their consequences for accessibility and equity for potential users of Mexican health services.

\section{Discussion and conclusions}

Given the sample framework adopted in this study, it is possible to extrapolate the results to the Mexican population as a whole. The fact that transport costs turned out to be greater for the population receiving care at Health Secretariat institutions, when compared to the population with social security coverage, shows that, in the context of the economic dimension of accessibility, Health Secretariat health services are less accessible geographically than social security health services. The same holds true for financial accessibility. 
Transportation costs by type of institution, insurance condition and annual household income level (in US\$).

\begin{tabular}{|c|c|c|c|c|}
\hline Income percentile & $\begin{array}{c}\text { Social security * } \\
\text { (estimated } \\
\text { population = } \\
1,572,938)\end{array}$ & $\begin{array}{l}\text { Health Secretariat } \\
\text { (estimated } \\
\text { population }= \\
382,362)\end{array}$ & $\begin{array}{l}\text { Private institutions } \\
\text { (estimated } \\
\text { population }= \\
1,026,839)\end{array}$ & $\begin{array}{c}\text { Others } \\
\text { (estimated } \\
\text { population = } \\
229,969)\end{array}$ \\
\hline \multicolumn{5}{|l|}{ Uninsured } \\
\hline US\$ 0.00 to US\$ 2,258 (4.2) & 4.28 & 4.08 & 2.97 & 4.62 \\
\hline$>$ US\$ 2,258 to US\$ 4,457 (3.4) & 1.82 & 1.68 & 2.97 & 0.82 \\
\hline$>$ US\$ 4,457 to US\$ 8,914 (3.1) & 1.28 & 2.25 & 5.31 & 2.02 \\
\hline$>$ US\$ 8,914 (2.6) & 0.20 & 0.82 & 1.80 & 2.62 \\
\hline \multicolumn{5}{|l|}{ Insured } \\
\hline US\$ 0.00 to US\$2,258 (26.1) & 1.48 & 3.45 & 3.68 & 0.45 \\
\hline$>$ US\$2,258 to US\$ 4,457 (3.4) & 2.05 & 1.20 & 1.94 & 4.65 \\
\hline$>$ US\$ 4,457 to US\$ 8,914 (3.1) & 1.97 & 5.51 & 3.62 & 0.77 \\
\hline$>$ US\$ 8,914 (2.6) & 1.05 & 1.20 & 1.57 & 0.54 \\
\hline
\end{tabular}

* Uninsured users who received care at social security institutions.

Notes: Duncan's test (<0.05); exchange rate at 10.5 Pesos per US\$1.00. January, 2006.

Table 2

Costs of consultation according to type of institution, insurance condition and annual household income level (in US\$).

\begin{tabular}{|c|c|c|c|c|}
\hline Income percentile & $\begin{array}{l}\text { Social security * } \\
\text { (estimated } \\
\text { population = } \\
1,950,083 \text { ) }\end{array}$ & $\begin{array}{l}\text { Health Secretariat } \\
\text { (estimated } \\
\text { population }= \\
883,890)\end{array}$ & $\begin{array}{l}\text { Private institutions } \\
\text { (estimated } \\
\text { population }= \\
1,518,402)\end{array}$ & $\begin{array}{c}\text { Others } \\
\text { (estimated } \\
\text { population = } \\
372,924)\end{array}$ \\
\hline \multicolumn{5}{|l|}{ Uninsured } \\
\hline US\$ 0.00 to US\$2,258 (23.6) & 2.74 & 4.20 & 17.20 & 1.68 \\
\hline$>$ US\$2,258 to US\$ 4,457 (19.6) & 1.54 & 4.45 & 15.91 & 7.31 \\
\hline$>$ US\$ 4,457 to US\$ 8,914 (14.8) & 0.71 & 4.77 & 18.37 & 5.77 \\
\hline$>$ US\$ 8,914 (11.2) & 6.48 & 6.58 & 27.65 & 3.37 \\
\hline \multicolumn{5}{|l|}{ Insured } \\
\hline US\$ 0.00 to US\$2,258 (3.7) & NA & 1.02 & 17.05 & 0.00 \\
\hline$>$ US\$2,258 to US\$ 4,457 (8.0) & NA & 2.14 & 18.25 & 1.37 \\
\hline$>$ US\$ 4,457 to US\$ 8,914 (7.5) & NA & 2.77 & 19.74 & 3.37 \\
\hline$>$ US\$ 8,914 (11.6) & NA & 2.17 & 26.05 & 4.28 \\
\hline
\end{tabular}

NA: not applicable.

* Uninsured users who received care at social security institutions.

Notes: Duncan's test (<0.05); exchange rate at 10.5 Pesos per US\$1.00. January, 2006

Accessibility was also affected by the urban or rural character of the community of origin. The cost of transportation for the rural population was more than double that for the urban population. These results are particularly interesting given that rural communities have the lowest annual incomes and their health is placed more at risk because of the poorer access to health care and their general living conditions.
At the same time, these results cast doubt on the value of the program policies implemented during the last few years, which are supposed to have been aimed at improving the health of the most vulnerable communities. In terms of accessibility and equity, there remains much to be done if the health system is to be made truly accessible to the poor. The cost of consultations also results in economic access problems for those on low incomes. 
Figure 2

Costs to users during the process of searching for and obtaining health care in Mexico.

\begin{tabular}{|l|}
\hline The behavior of users \\
The behavior of providers \\
\hline
\end{tabular}

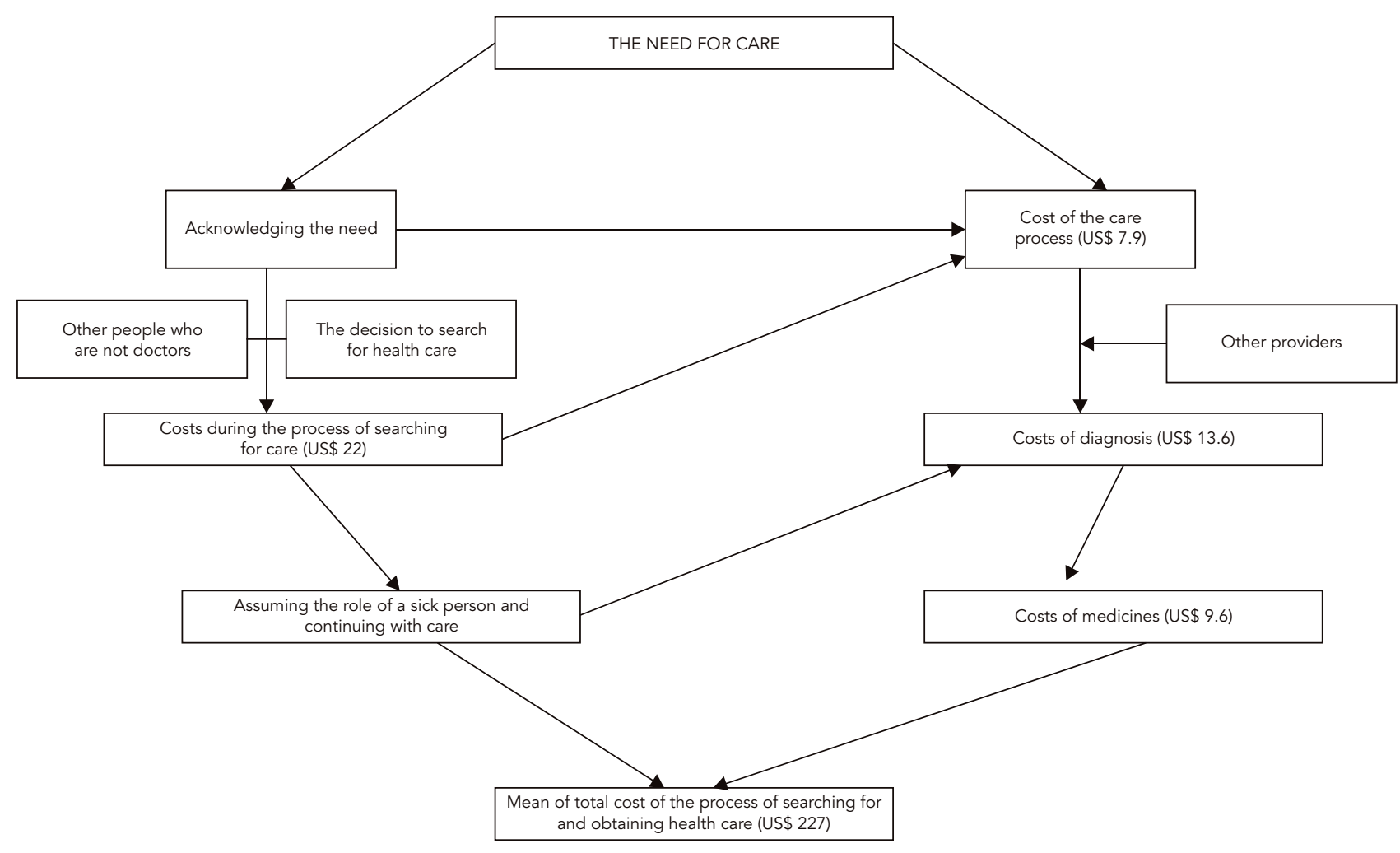

Note: exchange rate 10.5 Pesos per US\$1.00. January 2006.

In the case of drugs and diagnostic tests, the situation is more serious because in both cases their costs are actually even greater than the cost of care. This is especially so for diagnostic tests where the cost is almost double that of care. It is also important to point out that in the case of those who received care from the Health Secretariat (mostly the uninsured population), the cost of medicines was three times higher than care, and that of diagnostic services five times higher. This serves to highlight the problems of equity in accessibility particularly for the uninsured population.

It is the poor who have to pay more for medicines, a fact which goes against the principles of equity of access in the Mexican health system. There are substantial differences in the costs to the patient for consuming the same service, depending on the institution concerned. These differences are probably due to different levels of efficiency and to the different costs of production with which each institution operates. These results also reflect those in other studies at the national and international level, which show that within particular types of institutions, there are different levels of efficiency and differences in quality of care, and in combinations of inputs and costs of inputs 21,22,23,24.

When the same scheme that is proposed in Figure 1 is compared to data generated by the survey, we see that during the process of searching for and obtaining care, the population does not have enough information to allow them to go to their corresponding health center (by right or priority); this is supported by the fact that low income, uninsured users used and paid for services at social security or private sector institutions. 
The hypothesis that is derived from the above is that if a person sees himself/herself as having a serious health condition and has no right to social security, or the purchasing power to demand private health services, he/she might still request services at a nearby social security unit or a private clinic. This will happen even when public services for the uninsured may exist in the community where he/she lives but, due to the seriousness of the illness, he/she may search for services that are perceived as having a higher quality. However, due to his/her uninsured condition, free diagnostic studies and medicines will not be supplied, or he/she may have to pay for all private services. This is one of the typical cases where problems of equity and accessibility generate an increase in the costs of care.

At the level of health services planning, the results of this study can be used to highlight the effects of equity and accessibility problems that currently characterize Mexican health subsystems. The data obtained in this survey present relevant information on costs to the consumer which is fundamental for the development of health care programs that are more accessible and equitable.

User costs are substantial in terms of average family income; they are yet greater proportionately in the case of the uninsured population. This issue must be addressed if problems of equity, accessibility and efficiency are to be tackled, certainly better than is currently occurring in Mexico.

Finally, the paper highlights the fact that the analysis that was carried out is relevant to health systems in other middle income countries. The Mexican health system, which throughout its history has sought to act according to the principles of social justice (equity and accessibility), in practice turns out to be one which is inequitable: those who pay the most for health care in terms of care, transport, drugs and laboratory tests are the families with the lowest incomes. There is a need to rethink policy with respect to equity to ensure that the goal of equity is not just rhetoric but is realized.

\section{Resumen}

Se presentan los resultados de un estudio transversal, cuyo principal objetivo fue determinar los costos personales de los usuarios en el proceso de búsqueda, obtención y seguimiento de la atención a la salud en instituciones públicas y privadas del sistema mexicano de salud. La información fue obtenida de la Encuesta Nacional de Salud de México. La variable dependiente se refirió a los costos personales de los usuarios y como variables independientes se definieron la condición de aseguramiento, tipo de institución e ingreso económico. Los resultados sugieren que en países de ingresos medios los costos a los usuarios de servicios de salud requieren de un análisis muy detallado, ya que el sistema de salud esta fragmentado en asistencia pública, seguridad social y asistencia privada. Este estudio muestra evidencias de cómo los costos a los usuarios afectan de manera inequitativa a familias de menor ingreso y de mayor marginación social.

Equidad en Salud; Accesibilidad a los Servicios de Salud; Gastos en Salud

\section{Contributors}

The two authors were responsible for all phases of the research and for writing up the final article. 


\section{References}

1. Arredondo A, Carrillo C, Zuñiga A. Economic burden of expected epidemiological changes in diseases related to tobacco, Mexico. Rev Saúde Pública 2007 ; 41:523-9.

2. Contandriopoulos A-P, Souza L, Shardonofsky S, Brouselle A, Champagne F, Arredondo A. La investigación y enseñanza en economía de la salud. En: Contandriopoulos A-P, Souza L, Shardonofsky S, Brouselle A, editores. Entendiendo las transformaciones de los sistemas de salud: una perspectiva canadiense. Montreal: Universidad de Montreal/ Editoral GRIS; 2002. p. 24-36.

3. Musgrove P. The economic crisis and its impact on health and health care in Latin America and the Caribbean. Int J Health Serv 1990; 17:411-41.

4. Secretaría de Salud. Paquete básico de intervenciones en salud: costos de intervenciones. Informe final. México DF: Subsecretaría de Servicios de Salud; 1994.

5. Recursos para la salud en unidades de la Secretaría de Salud, 1999. Salud Pública Méx 2000; 42:252-9.

6. Frenk J, Lozano R, González-Block MA, Bobadilla J, Nigenda G, Arredondo A, et al. Proyecto economía y salud: informe final. 2a Ed. México DF: Fundación Mexicana para la Salud; 1995.

7. Arredondo A., Orozco E, De Icaza E. Financing indicators of health care decentralization in Latin American countries: information for health planning and financing. Int $\mathrm{J}$ Health Plann Manage 2005; 29:259-76.

8. Correa E, Noé M. Lineamientos estratégicos para el sector salud: desafíos del crecimiento con equidad. In: Sánchez H, Zuleta G, editors. La hora de los usuarios: reflexiones sobre economía política de las reformas de salud. Washington DC: Banco Interamericano de Desarrollo; 2005. p. 53-68.

9. Nájera P. Bases conceptuales y metodológicas de la Encuesta Nacional de Salud en México. Salud Pública Méx 1998; 40:76-85.

10. Sanabria C. Propuesta metodológica para el análisis de costos de servicios de salud. Revista de Ciencias Económicas 2002; 7:77-81.

11. Mills A, Gilson L. Health economics for developing countries. London: London School of Hygiene and Tropical Medicine, University of London; 1988. (Publication $n^{\circ}$. 17)

12. Drummond M, Stoddart G. Principles of economic evaluation of health programmes. World Health Stat Q 1985; 38:347-54.
13. Dunlop D, Zubkoff L. Inflación y comportamiento del consumidor. In: Organización Panamericana de la Saud/Organización Munidial de la Salud, editores. Análisis de costos, demanda y planificación de servicios de salud. Washington DC: Organización Panamericana de la Saud/Organización Munidial de la Salud; 2001. p. 221-61.

14. Donabedian A. Donabedian A. Aspectos de la administración de la atención médica. México DF: Fondo de Cultura Económica; 1988.

15. Freidson E. Types of lay referral systems. In: Freidson E, editor. Social construction of illness-profession of medicine. Chicago: University of Chicago Press; 1986. p. 292-5.

16. Giordano O, Colina J. Economía política de las reformas. In: Sánchez H, Zuleta G, editors. La hora de los usuarios: reflexiones sobre economía política de las reformas de salud. Washington DC: Banco Interamericano de Desarrollo; 2005. p. 13-26.

17. Hulka B, Wheat J. Patterns of utilization. Patient perspective. Med Care 1985; 23:438-60.

18. Rosenstock IM. Why people use health services. Milbank Mem Fund Q 1966; 44 (3 Suppl):94-127.

19. Hertzman C, Evans RG. Heterogeneitis in health status and determinants of population health. In: Evans RG, Barer M, editors. Why are some people healthy and others not? The determinants of health populations. New York: International Press Publication; 1997. p. 113-25.

20. Arredondo A, Orozco E. Equity, governance and financing after health care reform: lessons from Mexico. Int J Health Plann Manage 2008; 23:37-49.

21. Govindaraj R, Chellaraj G, Murray CJ. Health expenditures in Latin America and the Caribbean. Soc Sci Med 1997; 44:157-69.

22. Wodon QT. Poverty and policy in Latin America and the Caribbean. Washington DC: World Bank; 2000. (World Bank Technical Paper).

23. World Health Organization. World health report 2000. Health systems: improving performance. Geneva: World Health Organization; 2000.

24. Shahin Y. How equitable is public spending on health and education? Brighton: Poverty Research Unit, Sussex University; 2003.

Submitted on 23/May/2007

Final version resubmitted on 13/Dec/2007 Approved on 31/Jan/2008 